\title{
Investigation on Peroxidase Activity of Graviola (Annona muricata L.) at Different Stages of Fruit Development
}

\author{
S. Pandarinathan* \\ Anbil Dharmalingam Agricultural College \& Research Institute, \\ Tiruchirappalli-620 027, Tamil Nadu, India \\ *Corresponding author
}

\begin{tabular}{|c|c|}
\hline & A B S T R A C T \\
\hline & \multirow{4}{*}{ 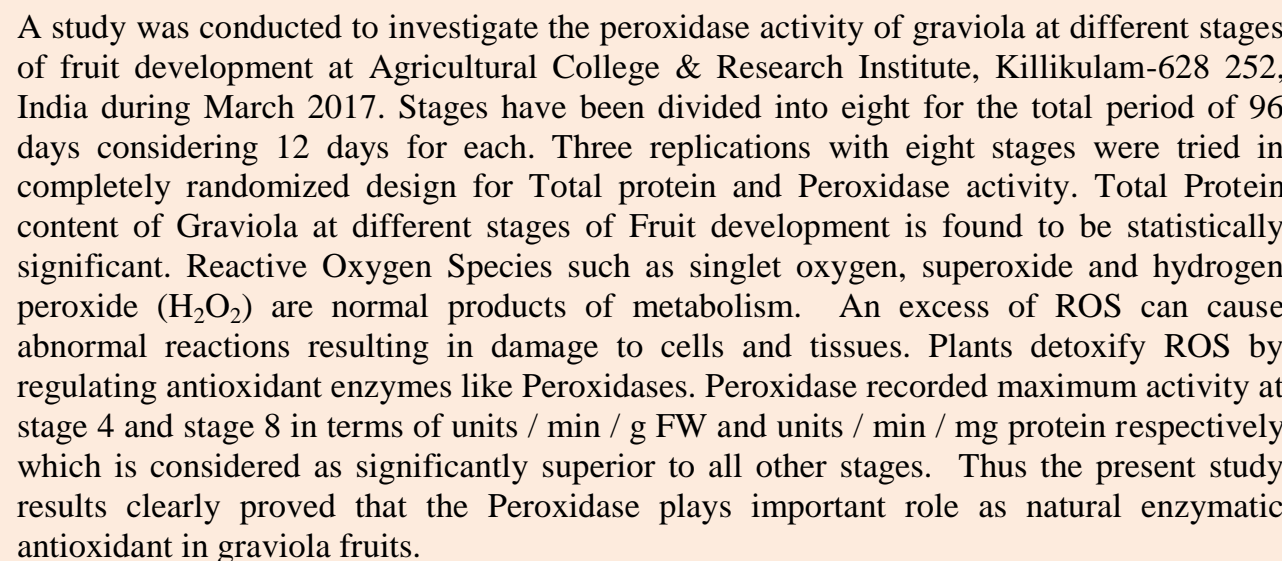 } \\
\hline $\begin{array}{l}\text { Cancer, Graviola } \\
\text { fruit, Peroxidase } \\
\text { enzyme, Protein } \\
\text { content, Soursop } \\
\text { tree }\end{array}$ & \\
\hline Article Info & \\
\hline $\begin{array}{l}\text { Accepted: } \\
\text { 10 June } 2019 \\
\text { Available Online: } \\
10 \text { July } 2019\end{array}$ & \\
\hline
\end{tabular}

\section{Introduction}

Annona muricata is known as Soursop (English), Graviola (Portugues), Guanabana (Latin American Spanish). This plant is species of the genus Annona, of the Annonaceae family, order Magnoliales and Division Magnoliophyta (Pinto et al., 2005).

Soursop is native to Central America, the Caribbean and Northern South America, Columbia and Brazil, Mexico, Peru and Venezuela and some Sub-saharan African countries that lie within the tropics (Morton and Julia, 1987). Graviola is now widely distributed throughout tropical and subtropical parts of the world, including India. Cultivation is restricted to a few countries where consumption is more widespread.

The genus name 'Annona' is from the Latin word 'anon', meaning 'yearly produce', referring to the fruit production habits of the various species in this genus. Graviola usually grown from seeds. Germination of seeds usually takes minimum 20 days. 
Annona muricata is a member of the Annonaceae family and is a fruit tree with a long history of traditional use. In general, In India, Alternative medicines are utilized by sufferer who does not require conventional medicines for serious pathological conditions.

Annona muricata is a slender, evergreen tree. Height of the tree is ranged between 5 and $8 \mathrm{~m}$ with straight trunk and spreading branches. Fruiting starts in the $2^{\text {nd }}$ year; depending on pollination efficiency and nutrient status fruiting occurs all year round. The plant may yield around 5 tons of fruit per hectare four years after planting, rising to 11 tons after 10 years.

The phyto-constituents that are naturally present in the plant exhibit disease preventive properties, though they are not essential nutrients to human health (Santhosh kumar et al., 2015)

By measurement of the respiration rate, soursop was classified as climacteric (Biale, J.B., and Barcus D.E., 1970).

All parts of the Annona muricata tree, used as traditional medicines against human diseases, especially cancer. Many studies had been done with leaf, root, stem and seed extracts of Annona muricata. Leaves and seeds of graviola plant have number of bioactive compounds with antitumour and antiparasitic properties.

Soursop fruit is a miraculous fruit with inedible skin covered with many soft spines. Fruit weighs up to $6 \mathrm{~kg}$, ovoid, heart shaped, fibrous and have approximately $15-21 \mathrm{~cm}$ in diameter. The unripe fruit is green and the pulp is white. When ripe, the skin becomes soft with yellowish green colour and the pulp becomes soft with juicy cream remains white. Soursop has a number of black-brown seeds looks shiny, oblong, up to $2 \mathrm{~cm}$ long and
$0.7 \mathrm{~cm}$ wide. The seed numbers are found to be highly variable among the individual fruits. The soursop fruit consists of $67.5 \%$ edible pulp, $20 \%$ peel, $8.5 \%$ seeds, and $4 \%$ core by weight (Sanchez-Nieva et al., 1953). The moisture content of completely ripened soursop pulp is ranged between 79 to $83 \%$. Sanchez-Nieva et al., 1970 found that Soursop pulp contained total solids, 16.618.6\%; total sugar (as invert sugar), 11.6$12.5 \%$; reducing sugars, 9.5-11.7\%; soluble solid, 15.8-17.4\% and $\mathrm{pH}$ 3.61-3.65. However, Chan and Lee (1975), reported a lower total value of sugars $(10.58 \%)$ detected as glucose, fructose and sucrose and Omoifo (2004) detected the maltose in soursop fruit juice.

Climate and Soil also make a significant influence on the variation in growth, fruit set, fruit size and quality of fruits (Pinto et al., 2005). Fruits were consumed for reducing fever and improving mother's milk secretion (Taylor, 2005). Soursop fruit is loaded with significant biomolecules and associated with various health benefits. The fruit pulp is usually eaten raw but it has been processed into different forms such as juice, jam and jellies. The main nutrients present in soursop are amino acids, Ascorbic acid (Vitamin C), Calcium, Carbohydrates, fibers, Iron, niacin, phosphorus, riboflavin, thiamine and phenolic compounds. Graviola fruit offers a lot of beneficial biomolecules for human health either to enhance the immunity or to cure the disease.

Annonaceous acetogenins are powerful bioorganic compounds found in the Graviola fruit tree, which are found only in Annonaceae family. These compounds have been found to have antitumor and anticancer property by arresting the activity of enzymes present only in the membranes of tumor/ cancer cells. Even though the principal bioactive compounds belong to A. muricata 
are Acetogenins, the present study focuses on enzyme activities for their role in prevention of cancer.

In a review article, Ana et al., 2018 stated that some phytochemical compounds isolated from $A$. muricata had showed a neurotoxic effect in vitro and in vivo studies. Optimal dosage can be fixed for compounds like Acetogenins and secondary metabolites for long-term safety. One need not bother about antioxidant enzyme like peroxidase activity since it will not have potential side effects.

Antioxidants and free radical scavenging potential were rich in the fresh than dry plant sources. Increased antioxidant levels can protect the human body from free radical damage. Free radicals are atomic or molecular species containing one or more unpaired electrons that can exist freely in solution (Halliwell, 1994).

Antioxidant activity can be defined as the protection against and repair of oxidative damage (Thompson et al., 2006).

Components of the enzymatic antioxidant system include: Superoxide dismutase; Catalase and glutathione peroxidase (GPx). The role of these enzymes is to convert free radicals into non-reactive species (Gupta, 2010).

In Tamilnadu, little industrial value is attached to this fruit and rarely displayed for sale in the market. This plant is to be cultivated commercially.

However, very little work has been done with soursop to highlight its potential use. Therefore, the current study was aimed and designed for protective role of graviola pulp peroxidase enzyme towards human healthy cells and a natural antagonistic role against human cancer cells.

\section{Materials and Methods}

Annona muricata fruits from Graviola trees at different stages of development were collected from the Graviola farm at Nagercoil, Tamil nadu, India. Selective plucking was done from tree tops and fruits were immediately separated into eight categories according to the target stages, each stage starting from 12 days interval.

The collections were made during dry season (March). Fruits which are free from mechanical injuries, insect damage or disease alone were collected for test samples. The fruits were hand peeled, cored and seeds separated from pulp. All determinations were done in triplicate.

\section{Reagents}

a. $0.1 \mathrm{M}$ Potassium phosphate buffer, $\mathrm{pH} 6.0$

b. $0.01 \mathrm{M}$ o-Dianisidine in methanol: prepared fresh

c. $0.02 \mathrm{M}$ Hydrogen peroxide $(20 \mathrm{mM})$ : Prepared fresh

d. 2N Sulphuric acid

Except otherwise stated, all chemicals used were of analytical grade.

\section{Determination of peroxidase activity}

Peroxidases catalyses the oxidation of a variety of electron donors with the help of $\mathrm{H} 2 \mathrm{O} 2$ thus scavenging the endogenous $\mathrm{H} 2 \mathrm{O} 2$ (Chamundeeswari et al., 2003).

\section{Enzyme extraction}

$1.0 \mathrm{~g}$ of fruit pulp sample was grinded with $0.1 \mathrm{M}$ potassium phosphate buffer, $\mathrm{pH} 6.0$ in a prechilled mortar and pestle and then, centrifuged at $16,000 \mathrm{~g}$ for $20 \mathrm{~min}$ at $4^{\circ} \mathrm{C}$. Supernatant was taken for the enzyme assay. The enzyme activity is assayed using o- 
dianisidine as hydrogen donor and $\mathrm{H} 2 \mathrm{O} 2$ as electron acceptor. The rate of formation of yellow orange coloured oxidized odianisidine product is a measure of the POD activity and assayed spectrophotometrically at 430nm (Modified summer and Gjessing, 1943).

\section{Calculation}

The change in absorbance per min was observed and expressed the peroxidase activity as units $/ \mathrm{min} / \mathrm{g}$ fresh weight of fruit pulp sample (Total activity) and units $/ \mathrm{min} / \mathrm{mg}$ protein (Specific activity) considering one unit of enzyme as an increase in Absorbance by 1.0 under standard conditions.

\section{Estimation of Total protein}

Concentration of Protein was determined spectrophotometrically at 550nm by Lowry's method using Bovine serum Albumin as a standard.

\section{Results and Discussion}

Soursop is a good source of nutrition and has many medicinal benefits. The optimum stage of eating is 5 days after harvest. At room temperature, Soursop has a shelf life limited to five days when it has been harvested at physiological maturity. There will always be a quality variation between ripe and unripe fruits. The Bio-chemical composition of soursops were influenced by varieties and environmental conditions related to production of fruit.

Immoderate generation of Intracellular reactive oxygen species (ROS) is a precursor of oxidative stress which subsequently catalyses metabolic deficiency and cellular death through biochemical and physiological lesions (Chance et al., 1979). Reactive Species are categorized into four groups: reactive oxygen species (ROS), reactive nitrogen species (RNS), reactive sulfur species (RSS) and reactive chloride species (RCS).

The most abundantly produced, among the four groups is ROS. They define as oxygen containing small species which are superoxide anion radical, hydroxyl radical, hydroxyl ion, hydrogen peroxide, singlet oxygen (Margaritelis, 2016).

Hydrogen peroxide ( $\mathrm{H} 2 \mathrm{O} 2)$ is a well-known ROS that is formed during normal metabolism, where it is produced in the brain during the catalytic degradation of neurotransmitters such as dopamine and it is estimated that $3 \%$ of body's hemoglobin is auto oxidized daily to produce $\mathrm{H} 2 \mathrm{O} 2$ (Sakihama et al., 2002).

GSH is the primary redox buffer in all human neuronal cells and when two molecules of GSH combine to form oxidized glutathione (GSSH), two reducing equivalents of $\mathrm{H}+$ are made available for the quenching of ROS, thereby protecting human cells from oxidative damage (Waly, 2016).

The identification of antioxidant enzymes and its activity from natural sources has become important in nullifying the destructive effects of ROS.

However, the inhibition of enzymes distributed in membranes of cancer cells may confer nutraceutical solution towards the management of diseases.

There are over 100 different types of cancer, and each is classified by the type of cell that is initially affected and these include cervical cancer, skin cancer, leukemia, lung cancer, prostate cancer and so on (Ozbay et al., 2011). Carcinogenesis is a multistep process. Dietary nutraceuticals has a good impact on prevention of cancer by targeting multiple pathways. Whole foods may provide benefits that exceed those of isolated single nutraceuticals. 
Fruit pulps are considered to be a good source for enzyme. In general, it is advised to consume the fruit pulp as such in order to retain the nutrient concentrations and the activity of enzymes. To increase the demand and reduce the wastage of graviola fruit, value added products can be produced.

Knowledge on the fruit quality parameters by fruit growers and fruit consumers is lacking.

Null research on parameters of Top five antioxidant enzymes in Graviola fruit pulp were carried out. This might be the first study on the determination of Peroxidase activity of Graviola at different stages of fruit development.

\section{Statistical analysis}

The variance analysis $(\mathrm{a}=5 \%)$ was performed to test the difference in the results using a completely randomized design (CRD) with three replications of the experiments. Total Protein content of Graviola at different stages of Fruit development is found to be statistically significant at 5\% level of significance (Table 1).

\section{Statistical comment for peroxidase activity} (units / min / g FW)

The results reveal that Peroxidase activity at stage 4 was found to be superior when compare to other stages.

\section{Statistical comment for peroxidase activity (units / min / mg protein)}

The results reveal that Peroxidase activity at stage 8 was found to be superior when compare to other stages.

Table. 1 Total protein content and changes in peroxidase activity of Graviola at different stages of fruit development

\begin{tabular}{|l|l|l|l|l|}
\hline Stages & Day & \multicolumn{2}{|c|}{$\begin{array}{c}\text { Mean } \\
\text { Peroxidase Activity }\end{array}$} & $\begin{array}{l}\text { Mean } \\
\text { Total Protein }(g / 100 g\end{array}$ \\
\cline { 3 - 6 } & & (units / min / g FW) & (units / min / mg protein) & FW) \\
\hline S1 & $12^{\text {th }}$ day & 1386.66 & 68.807 & $\mathbf{2 . 0 1 5}$ \\
\hline S2 & $24^{\text {th }}$ day & 1568.66 & 120.673 & 1.300 \\
\hline S3 & $36^{\text {th }}$ day & 1716.00 & 146.669 & 1.170 \\
\hline S4 & $48^{\text {th }}$ day & $\mathbf{1 8 7 2 . 0 0}$ & 169.404 & 1.105 \\
\hline S5 & $60^{\text {th }}$ day & 1664.00 & 170.665 & 0.975 \\
\hline S6 & $72^{\text {nd }}$ day & 1584.00 & 174.081 & 0.910 \\
\hline S7 & $84^{\text {th }}$ day & 1508.00 & 178.462 & 0.845 \\
\hline S8 & $96^{\text {th }}$ day & 1404.00 & $\mathbf{1 8 0 . 0 0 1}$ & 0.780 \\
\hline Statistical & SEm & 27.29 & 2.931 & 0.005 \\
\cline { 2 - 5 } Analysis & SEd & 38.59 & 4.146 & 0.007 \\
\cline { 2 - 5 } & CD $(1 \%)$ & 108.35 & 11.639 & 0.019 \\
\cline { 2 - 5 } & CD $(5 \%)$ & 79.84 & 8.577 & 0.014 \\
\hline
\end{tabular}

Where: SEm: Standard Error mean, SEd: Standard Error deviation, CD: Critical Difference

In conclusion, the present study results strongly suggest the potential use of
A.muricata fruit as a natural source for antioxidant enzyme peroxidase. 
The finding of the study reveals that soursop pulp could be considered as the best source for peroxidase activity meant for prevention of human diseases caused by oxidative stress.

This study report warrant an in depth analysis for the utility of Graviola fruit pulp as component source for chemotherapic resistant tumor / cancer cells. Further, Clinical studies are necessary to do to support the therapeutic potential of antioxidant enzymes of Graviola fruit.

In spite of many advances in modern scientific medicine, plant-based traditional medicine still plays a significant role in human health. Soursop can be referred as 'Complete medicinal plant' since none of its part is worthless.

Dietary supplements are now made using different fruits and vegetables to improve the health.

Healthy eating is associated with the consumption of fruits, which are notable for their beneficial effects on human health. Regular consumption of antioxidant rich fruits will reduce cellular oxidative stress and will protect against health related problems.

Fruit pulps have huge importance as raw material, taken at harvest can be stored and processed according to the demand of the consumer market.

Frozen pulp can be used in preparation of ice cream and ice cream related products.

A positive correlation will be there between Peroxidase activity of Soursop pulp and extension of lifetime of human beings.

A proper and in depth scientific investigation on A. muricata will open doors to conquer threatening pathological conditions like cancer. This underutilized and unexploited fruit may be considered as 'Anticancer fruit' because of its biochemical constituents.

Soursop fruit can be recommended for cancer prevention and the reduction in size of tumours.

Graviola fruit trees cultivation could be promoted and the fruits can be commercialized because of its sensory acceptance, nutritional profile, functional and therapeutic benefits.

\section{Acknowledgment}

The author is thankful to Prof. Dr.N. Richard Kennady, Department of Horticulture, Floriculture Research Station, Thovalai-629 302, Kanyakumari district for providing Graviola fruit samples for this research work.

\section{References}

Ana V. Coria-Tellez, Efigenia MontalvoGonzalez, Elhadi M. Yahia, Eva N. Obledo-Vazquez. 2018 Annona muricata: A comprehensive review on its traditional medicinal uses, phytochemicals, pharmacological activities, mechanisms of action and toxicity. Arabian journal of chemistry. 11, 662-691.

Biale, J.B., and Barcus, D.E. (1970). Respiratory patterns in tropical fruits of the Amazon Basin. Tropical Science, 12, 93-104.

Chamundeeswari D, Vasantha J, Gopalakrishnan S, Sukumar E, J. Ethropharmacology, 2003, 88(1), 51-56.

Chan. H.T.Jr. and Lee, C.W.O.1975 Identification and determination of sugars in soursop, Rose apple, mountain apple and Surinam cherry, Journal of Food science, 40: 892-893.

Chance, B.; Sies, H.; Boveris. A. Hydroperoxide metabolism in mammalian organs. Physiol. Rev. 1979, 
59, 527-605.

C.O. Omoifo 2004. Biochemical composition of soursop fruit, Annona muricata L., as affected by Two harvest seasons. Tropical Agricultural Research and Extension, 7:23.

Gupta V (2010) Comprehensive Bioactive Natural Pro. Stadium press, LLC, USA.

Halliwell B (1994) Free radicals and antioxidants: A personal view. Nutr Rev 52: 253-265.

Lowry, O.H., N.J. Rosebrough, A.L. Farr, and R.J. Randall (1951). J.Biol.Chem., 193, 265.

Margaritelis NV (2016) Antioxidants as therapeutics in the intensive care unit. Have we ticked the redox boxes? Pharmacol Res 111:126-132.

Morton, Julia F. Soursop (Annona muricata). (1987) Fruits of warm climates. Purdue University. pp 75-80.

Ozbay T, Nahta R. Delphinidin inhibits HERZ and Erk $1 / 2$ signaling and suppresses growth of HERZ overexpressing and triple negative breast cancer cell lines. Basic Clin Res 2011; 5:143-54.

Pinto, A.C., de, Q., Cordeiro, M.C.R., De Andrade, S.R.M., Ferreira, F.R., Figueiras, H.A., de, C., Alves, R.E., Kinpara, D.I., 2005. Annona muricata. In: Williams, J.T.(Ed.), Annona species, Taxonomy and Botany, Inter-national center for underutilized crops, University of Southampton, Southampton, UK, pp.3-16.

Sanchez-Nieva, F., Hernandez, I., Iguina de George, L.M. 1970 Frozen soursop puree. Journal of Agriculture of the University of Puerto Rico, 54: 220-236.

Sanchez-Nieva, F., Igaravidez, L., \& LopezRamos, B. (1953). The preparation of soursop nectar. University of Puerto Rico Agriculture Experimental stational Technical Paper, 11, 5-19.

Santhosh kumar Muthu and Brindha Durairaj, 2015. Evaluation of antioxidant and free radical scavenging activity of Annona muricata. Euro.J.Exp.Bio.,5(3):39-45

Sakihama Y, Cohen MF, Grace SC, Yamasaki $\mathrm{H}$ (2002) Plant phenolic antioxidant and prooxidant activities: phenolics-induced oxidative damage mediated by metals in plants. Toxicology 177 (1): 67-80.

Summer, J. B. and Gjessing, E.C.1943. Determination of Peroxidase activity. Arch. Biochem, 2: 291.

Taylor L, Technical Data report for Graviola (Annona muricata), Sage press, Austin, TX, 2005, pp56.

Thompson J, Manore M (2006) Nutrition: An Applied Approach, My pyramid Edition. Benjamin Cummings, USA.

Waly MI, Guizani N (2016) Health aspects of antioxidant nutrients: a concise update. OAJAR 1 (1): 1-6.

\section{How to cite this article:}

Pandarinathan, S. 2019. Investigation on Peroxidase Activity of Graviola (Annona muricata L.) at Different Stages of Fruit Development. Int.J.Curr.Microbiol.App.Sci. 8(07): 1150-1156. doi: https://doi.org/10.20546/ijcmas.2019.807.136 